\title{
Acute mountain sickness amongst tourists to Lhasa
}

\author{
Gaurav Sikri ${ }^{*}$ and Srinivasa Bhattachar
}

\begin{abstract}
Acute mountain sickness is the commonest acute high altitude illness occurring at high altitude. Its prevalence is dependent on the ascent rate, altitude achieved, physical effort required to reach the target altitude and pharmacological intervention undertaken by the tourists visiting high altitude areas. This Letter to the Editor is an endeavour to re-emphasise the importance of all these factors affecting the prevalence of acute mountain sickness.
\end{abstract}

\section{To the Editor}

We read with profound interest the article titled 'Acute mountain sickness among tourists visiting the highaltitude city of Lhasa at $3658 \mathrm{~m}$ above sea level: a crosssectional study' by Gonggalanzi et al. [1]. Indeed this study is one of its kind, which involved evaluation of a large sample size of ordinary travellers to Lhasa for acute mountain sickness (AMS). As reported by the authors, $47.3 \%$ (1022 out of 2160) tourists travelled to Lhasa by means other than air (by road, rail and train) and 35.9\% of them suffered from AMS. It would be interesting to know the ascent profile and travel history of these subjects. Their travel details like starting altitudes, travel time and average ascent rates would have elucidated further the effects of mode of travel/induction to high altitude (HA) on occurrence of AMS as many of the travel related symptoms in HA terrain like fatigue, motion sickness etc. may imitate symptoms included in questionnaire based on Lake Louise scoring system (LLSS).

Authors have mentioned that $46.4 \%$ (965 out of 2081) of the tourists used various prophylactic agents in the present study. As per Wilderness Medical Society guidelines, the prophylactic agents generally used against prevention of acute high altitude illnesses are classified into two groups: one group consisting of drugs used against AMS/high altitude cerebral edema (acetazolamide, steroids) and other group having drugs used against high altitude pulmonary edema (nifedipine) [2]. Evaluation of effects of these drugs as one combined group by the

* Correspondence: drgaurav35@gmail.com

Department of Physiology, Armed Forces Medical College, Wanowarie,

Sholapur Road, Pune, Maharashtra 411040, India authors and reporting of occurrence of AMS does not bring out their actual relationship. It would have been nice if authors had evaluated the relationship between AMS and drugs used specifically against it. Also, elaboration on history of drug intake like timings of starting/ stopping medication and dosage would have explained this relationship better in travellers to Lhasa.

As acknowledged by the authors, AMS is generally known to occur 6 to $12 \mathrm{~h}$ after ascending beyond $2500 \mathrm{~m}$ [3]. But the data presented in this study may not actually support this because of a possible 'recall' bias because of lack of uniformity in filling and submitting questionnaires based on LLSS. It would have been interesting if the tourists were asked to fill the questionnaires after a specific time say after 12 or $24 \mathrm{~h}$ of ascent to $3658 \mathrm{~m}$. This could have reduced this possible bias and helped in comparison of outcome of the present study with other studies at similar altitudes.

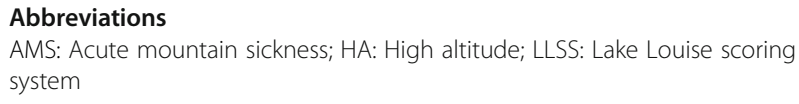

Acknowledgement

Not applicable.

Funding

Not applicable.

Availability of data and materials

Data sharing not applicable to this article as no datasets were generated or analysed during the current study.

\section{Authors' contributions}

GS and SB contributed equally in writing of this manuscript. Both authors have read and approved the final manuscript. 


\section{Competing interests}

The authors declare that they have no competing interests.

\section{Consent for publication}

Not applicable.

Ethics approval and consent to participate

Not applicable.

Received: 12 December 2016 Accepted: 20 December 2016

Published online: 27 January 2017

\section{References}

1. Gonggalanz, Labasangzhu, Nafstad P, Stigum H, Wu T, Haldorsen ØD,

Ommundsen K, Bjertness E. Acute mountain sickness among tourists visiting

the high-altitude city of Lhasa at $3658 \mathrm{~m}$ above sea level: a cross-sectional study. Arch Public Health. 2016;74:23. doi:10.1186/s13690-016-0134-z.

2. Luks AM, Mclntosh SE, Grissom CK, Auerbach PS, Rodway GW, Schoene RB, Zafren K, Hackett PH. Wilderness medical society practice guidelines for the prevention and treatment of acute altitude illness: 2014 update. Wilderness Environ Med. 2014;25:S4-S14.

3. Bartsch P, Swenson ER. Acute high altitude illnesses. N Engl J Med. 2013; 368:2294-302

Submit your next manuscript to BioMed Central and we will help you at every step:

- We accept pre-submission inquiries

- Our selector tool helps you to find the most relevant journal

- We provide round the clock customer support

- Convenient online submission

- Thorough peer review

- Inclusion in PubMed and all major indexing services

- Maximum visibility for your research

Submit your manuscript at www.biomedcentral.com/submit
Biomed Central 